\title{
Violent Conflicts and Threatened Lives: Nicaraguan Experiences of Wartime Displacement and Postwar Distress*
}

\author{
ANJA NYGREN
}

Abstract. This article utilises an ethnographic case study from Nicaragua to analyse people's everyday experiences of wartime violence and postwar privation. A great deal of literature dealing with political instability in war-torn countries has approached this issue by examining the societal manifestations of violence, while relatively less attention has been paid to people's everyday experiences of conflict and pain. This study focuses on the several waves of violence, displacement, and distress Nicaraguan people have suffered in recent years, beginning with their traumatic experiences of the civil war in the i 980 os to the current postwar era characterised by political instability and socio-economic insecurity.

\section{Introduction}

In recent decades, increasing numbers of persons in Africa, Asia, Europe, and Latin America have been forced to leave their homes as a result of armed conflicts, human rights violations and forced dislocations. According to the United Nations' Secretary-General, Kofi Annan, human displacement has emerged as one of the great tragedies of our time. ${ }^{1}$ Many of the major cases of displacement during the r970s and I980s took place in states that were the locus of Cold War proxy conflicts, including Angola, Guatemala,

Anja Nygren is Research Scholar at the University of Helsinki and Visiting Scholar at the University of Missouri-Columbia.

* This article draws on research financed by the Academy of Finland. I am grateful to the people of Río San Juan and to the many ministries, development institutions and NGOs in Nicaragua that co-operated with my field research. I am also grateful to Universidad Centroamericana (UCA) and the School of Natural Resources at the University of MissouriColumbia for providing logistic support. Sandy Rikoon and the two anonymous reviewers of this journal provided highly relevant comments on a previous version of this article.

1 Kofi Annan, 'Preface,' in Roberta Cohen and Francis Deng, Masses in Flight: The Global Crisis of Internal Displacement (Washington DC, I 998), pp. xix-xxi. Displacement refers to persons who have been obliged to leave their homes because of armed conflict, human rights violations, or natural or human-made disasters. Refugees have crossed an internationally recognised state boundary, while internally displaced people remain within their national borders. Cohen and Deng, Masses in Flight, pp. I 8-20. 
Mozambique, Nicaragua and El Salvador. The ending of the Cold War markedly contributed to the decline of these civil conflicts and to the initiation of rehabilitation processes that returned large numbers of refugees and internally displaced persons to their homes. It was only then that the plight of these people affected by violent wars and forced into a life of indignity came into full view.

Civil wars, particularly when they divide countries along political and religious lines, do not resolve themselves neatly. The war often leaves deep wounds within society and many people suffer from physical and psychological trauma. Peace-building and reconstruction in war-torn societies depend largely on the effective reintegration of uprooted people. In Central America alone, hundreds of thousands of people were uprooted by violent conflicts during the Cold War. The plight of these people poses a challenge with significant humanitarian, political, and strategic dimensions.

The purpose of this article is to examine the different waves of violence, displacement, and distress that the Nicaraguan people have suffered in recent years, beginning with their traumatic experiences of the civil war in the I980s and extending to the current postwar era characterised by socio-political polarisation and economic destitution. The study focuses on the everyday adversities of Nicaraguan life through an ethnographic case study from the municipality of El Castillo, Río San Juan, in southeastern Nicaragua. The inhabitants of El Castillo and the surrounding region underwent shattering experiences of dislocation during wartime, as the area became an intensive battle zone and a site of massive refugee flows and displacement operations. The current postwar era has been marked by devastating economic and socio-political instability.

The international community's interest in establishing 'political order' in war-torn societies has often focused on democratic elections. However, free and fair elections do not necessarily transform the society's deep-rooted political conflicts and social asymmetries. ${ }^{2}$ These issues are highly relevant in Nicaragua, where peace negotiations were readily equated with demobilisation and subsumed under the process of regime transition. A host of related issues were insufficiently addressed, including the social reinsertion of uprooted people, opening political space for marginalised sectors, and creation of mechanisms for large-scale reconciliation. All of this has fostered a climate of resentment in postwar Nicaragua. ${ }^{3}$

${ }^{2}$ Krishna Kumar, 'The Nature and Focus of International Assistance for Rebuilding WarTorn Societies,' in Krishna Kumar (ed.), Rebuilding Societies after Civil War: Critical Roles for International Assistance (Boulder, i 997), p. 2.

${ }^{3}$ Rose J. Spalding, 'From Low-Intensity War to Low-Intensity Peace: The Nicaraguan Peace Process,' in Cynthia J. Arnson (ed.), Comparative Peace Processes in Latin America (Stanford, I 999), pp. 3 I-64. 
Reconstruction in war-torn societies is a long and painful process. Conflict resolution is not just about the end of fighting, but about the restoration of law and order, respect for human rights and improvement of the socioeconomic situation of the majority. Unless the inequalities and injustices which have been the source of tension are addressed, new cycles of violence are likely to occur. ${ }^{4}$ Human memory is often slower than official agreements. It may take years before people shattered by civil conflicts are able to recover. Notwithstanding, psychosocial rehabilitation has been a neglected topic in post-conflict reconstruction. Relatively little research has been carried out on the impact of wartime violence and postwar instability on people's everyday lives. ${ }^{\mathbf{5}}$ In recent years a number of anthropologists have emphasised the insidious and pervasive effects of violence and distress, underscoring how terror and anguish operate at the level of lived experiences. These studies indicate that analysing the subjective dimensions of conflict and the embodied histories of poverty may provide important insights into understanding how conditions of violence and privation affect everyday dimensions of social life. ${ }^{6}$

The same matter concerns the issue of postwar democratisation. As noted by Jonas, we should not assign the label of 'democracy' to situations that are not experienced as such by most of the citizens. The democracy may be easily delegitimised, if significant numbers of citizens perceive that they have little ownership of the recovery process. ${ }^{7}$ In this sense, Nicaraguan democracy remains fairly fragile.

Beyond the debate about postwar democratisation lies the highly contested question of its relation to socio-economic equality. International relief programmes have often focused on 'crisis management' in war-torn countries, without sufficient consideration of the long-term processes of economic and social recovery. However, democratisation is not possible without a minimum concern for social justice and without minimum conditions for

${ }^{4}$ Geoff Harris and Neryl Lewis, 'Armed Conflict in Developing Countries: Extent, Nature and Causes,' in Geoff Harris (ed.), Recovery from Armed Conflict in Developing Countries: An Economic and Political Analysis (London, I999), p. 32.

${ }^{5}$ For inspiring exceptions, see Linda Green, 'Fear as a Way of Life,' Cultural Anthropology vol. 9, no. 2 (1994), pp. 227-56, Donny Meertens, 'Facing Destruction, Rebuilding Life: Gender and the Internally Displaced in Colombia,' Latin American Perspectives, vol. 28, no. I (200I), pp. I 32-48, J. Quesada, 'Contested Lives, Contested Territories: An Ethnography of Polarization, Distress, and Suffering in Post-Sandinista Nicaragua,' unpubl. PhD diss., University of California, I 994.

${ }^{6}$ See V. Das et al. (eds.), Violence and Subjectivity (Berkeley, 2000), R. N. Lancaster, Life is Hard: Machismo, Danger, and the Intimacy of Power in Nicaragua (Berkeley, 1992), C. Nordstrom and J. Martin (eds.), The Paths to Domination, Resistance, and Terror (Berkeley, I 992), N. ScheperHughes, Death without Weeping: The Violence of Everyday Life in Brazil (Berkeley, 1992).

7 Susanne Jonas, 'Can Peace Bring Democracy or Social Justice? The Case of Guatemala,' Social Justice vol. 25 no. 4 (1998), p. 40. 
people to satisfy their basic needs. ${ }^{8}$ Nicaragua provides a powerful lesson about the problems connected with a government's lack of responsibility for the needs of the population, especially for the most marginalised sectors. With US $\$ 2,700$ of GDP per capita, Nicaragua is the Western Hemisphere's second poorest country, after Haiti. ${ }^{9}$ About 48 per cent of the population are poor, and 17 per cent of them are extremely poor. The richest io per cent of the population have an average income nineteen times larger than that of the poorest 40 per cent, and the richest 20 per cent consume 5 I per cent of the country's total consumption. ${ }^{10}$ Under these conditions, many people are unable to attend to their most basic needs. They suffer from illiteracy, unemployment, poor health, limited political representation and limited control of their lives. ${ }^{11}$

This study intends to put a human face on the adversities Nicaraguan people face under these conditions of political and socio-economic instability. It aims to understand the sense of anxiety that permeates people's lives wracked by traumatic memories of war and persistent concerns about their physical and emotional survival. The first section of the article gives a brief description of the socio-political context of the research area. People's experiences of war, terror and dislocation are then examined. The third section analyses the difficult process of demobilisation, while the fourth and fifth sections focus on people's postwar experiences of economic distress and political violence. The final section reveals the diverse strategies by which people try to struggle against the problems of precariousness and marginality.

\section{Río San Juan as an arena of multiple struggles}

Nicaragua is a country overwhelmed by its history. For centuries, Nicaraguan society has suffered from civil wars, foreign interventions, unequal distribution of wealth and income and socio-political polarisation. ${ }^{12}$ This is especially true in Río San Juan. This transborder area between Nicaragua and Costa Rica has historically been one of Central America's most conflictive areas. It was the site of armed invasions by British pirates, Miskito raiders, the British navy, US filibusters, inter-American military strategists, Sandinista

8 Ibid., pp. 40-75.

9 Central Intelligence Agency (CIA), The World Factbook, 2000 (Washington, DC, 2000).

10 'A Strengthened Growth and Poverty Reduction Strategy,' unpubl. docum., Government of Nicaragua, 200 I, pp. 5-8.

11 Poverty is a multidimensional problem and a difficult concept to define. Its most common definition is in terms of unacceptably low levels of income and consumption. In addition, poverty is often associated with unsatisfied basic needs, high vulnerability to exogenous events, and lack of economic opportunities. Many dimensions of poverty are difficult to quantify. See A. Sen, Inequality Reexamined (New York, 1992).

12 Thomas W. Walker, 'Introduction: Historical Setting and Important Issues,' in Thomas W. Walker (ed.), Nicaragua without Illusions (Wilmington, I997), pp. I-I 9. 
insurgents and anti-Sandinista guerrillas. ${ }^{13}$ The area has been marked by a series of boom-and-bust economic cycles typical for tropical forest frontiers, such as exploitation of rubber, chicle and timber. Due to its remoteness, Río San Juan is also a favourable terrain for clandestine activities, such as illegal natural resource trade and contraband of arms and drugs. ${ }^{14}$

Until the i95os scattered hamlets of smallholders existed throughout Río San Juan's hinterland. These households cleared small patches of forest for crop production, and they also practised forest extraction. The more accessible areas of the region were in the hands of large landholders. During the I 960 s and I970s, a wave of colonists entered the region, principally smallholders from Pacific areas who had lost their lands to cattle estates and cotton plantations. These people began to open up the Río San Juan forests to slashand-burn agriculture. In the early I 980 s violent guerrilla conflict broke out in the region. Thousands of people were displaced from their homesteads to government-established settlements while many of those who opposed the government's actions left as refugees for Costa Rica. Since 1990 a considerable number of displaced people have returned to their farms. At the same time, the flow of new colonists entering the region has dramatically increased. ${ }^{15}$

Most of the current inhabitants are non-indigenous smallholders (campesinos) who cultivate basic crops by slash-and-burn agriculture and supplement their livelihood with small-scale cattle husbandry, logging and trading. Many of them also participate in two-step migration, which involves clearing land for pasture and then selling it to land speculators. Many of these smallholders face serious crises of survival within a context where access to free land has ceased, crop productivity is low, and hierarchical forms of commercialisation, with different kinds of intermediaries, make it difficult for them to compete in markets.

In recent years, Río San Juan has also become a site of heated negotiation over natural resource use. Since the establishment of the biological reserve of Indio-Maíz in the eastern part of Río San Juan in I990, there have been intense struggles over protection and production in the region. IndioMaíz is one of the largest protected areas in Nicaragua, covering 264,000 hectares of land. It belongs within the category of strictly protected areas; the only activities permitted inside the reserve are scientific research and wilderness protection. ${ }^{16}$ The buffer zone of the reserve - the main area of this

13 J. Rabella, Aproximación a la bistoria de Río San Juan, I500-1995 (Managua, I995).

14 Pascal O. Girot and Bernard Q. Nietschmann, 'The Río San Juan: The Geopolitics and Ecopolitics of the Río San Juan,' National Geographic Research \& Exploration, vol. 8, no. I (1992), pp. 52-63.

15 P. Utting, Trees, People and Power: Social Dimensions of Deforestation and Forest Protection in Central America (London, i 993), pp. 86, I48-50.

16 Instituto de Recursos Naturales (IRENA), Plan de acción forestal (Managua, I992). 
study - includes I 80,000 hectares of land and some I 5,000 inhabitants. ${ }^{\mathbf{1 7}}$ According to the Territorial Agreement of I99I, land use practices in the buffer zone are restricted to those that maintain the biodiversity of the reserve. This goal is, however, complicated by the fact that the buffer zone is also one of the most intensive agricultural frontiers in the country, with high rates of deforestation.

This contradiction has provoked a series of conflicts between the local inhabitants and conservation programmes underway in Río San Juan. While conservation authorities consider Indio-Maíz to be one of the least disturbed rainforests in Central America, and one that should be preserved free from human interference, local inhabitants argue that the protection of nature has no justification if it ignores local livelihood requirements. These resourcepoor peasants fear loss of access to resources and livelihoods in a locale where reserve managers advocate restricted resource use throughout the reserve's buffer zone.

This study is based on a year's anthropological field research carried out in Río San Juan in 1996-98. The principal methods included in-depth interviews, participant observation and daily conversations with local inhabitants and dozens of conservation authorities, development experts, and grassroots activists. The primary data consists of ninety hours of tape-recorded interviews, supplemented by existing archive and statistical material, development reports and historical documents. ${ }^{18}$ As will be shown during the following analysis, the life-stories of the people of Río San Juan are a mixture of hope and despair, survival and loss, and struggle and resistance. They express intense conflicts over resources, bitter socio-political divisions, and the strains of living in chronic privation. At the same time, these accounts tell of the people's tireless search for relief, their astonishing perseverance, and their inventiveness in a context of adversity. These stories are a vital means through which the people reconstruct their lives in the aftermath of the war. ${ }^{19}$

17 'Documento de proyecto manejo sostenible de la zona de amortiguamiento, Nicaragua,' unpubl. docum., Danish International Aid Agency (DANIDA), I 998, pp. 3-5.

18 Except where explicitly mentioned, the material presented is based on my own field data.

19 When conducting in-depth interviews among the people of Río San Juan, I faced many ethical questions about who has the right to speak on behalf of these people. It became obvious that ethnographic interaction is never simply a transmission of information, but it also includes complex phases of interpretation, where the ethnographer has much power to choose between different representations. By controlling the flow of information, the informants also effected a power relationship with me. At times, the details people gave of their lives became contradictory and some people clearly modulated the information, concealing their past and dramatising their destiny. It also became apparent that the climate of tension that characterised Río San Juan shaped the nature of my interaction with local people. Some of them were reluctant to participate in interviewing, especially in the early phases of the research, while others' responses were affected by fear and suspicion. For similar problems in conducting fieldwork among traumatised people, see Green, 'Fear as a 
War, displacement and exile

During the Somoza dictatorship from 1936 to I979, the smallholders of Río San Juan lived in miserable marginalisation. In 1978 , about 88 per cent of the cultivated land in Río San Juan was in the hands of large landowners who represented three per cent of all landowners in the region. The illiteracy rate was recorded at 96 per cent of the population and the average life expectancy was among the worst in the country. ${ }^{20}$ The Insurrection War (1978-79) against Somoza united the nation, but the revolutionary transformation initiated by the subsequent Sandinista government was not universally supported. The upper class and the private sector blanched at the government's radical redistribution of wealth and income, while the Catholic Church hierarchy resisted the Sandinistas' Marxist ideology. ${ }^{21}$ The conflicts sparked by the transition gave rise to the Contra War (1981-90).

In Río San Juan heavy fighting flared up in 1982 when a faction of the Resistance (Contra) army began to operate in the region. The Contra base camps were established on the Nicaraguan side, while the training camps were on the Costa Rican side. To undermine the social base of support for the Contras, the government displaced some I,400 peasant families from their forest homesteads to government-established settlements situated in more controllable areas. These displacements caused unrest among the local population and gave rise to misunderstandings between the authorities and campesinos. Thousands of people, many of them sympathetic to the Contras, who opposed the government's decision to resettle them sought refuge in Costa Rica. ${ }^{22}$

The Sandinista agrarian reform significantly transformed the land tenure system in Río San Juan, as elsewhere in the countryside. Between 1979 and I98 I, the government confiscated all rural properties owned by Somoza and his close associates and turned these holdings into state farms. In I98 I, officials began to distribute land to agricultural co-operatives, and in 1985 , the government started to redistribute land to individual small farmers. ${ }^{23}$ The

Way of Life,' Nordstrom and Martin, The Paths to Domination, C. Nordstrom and A. Robben (eds.), Fieldwork under Fire: Contemporary Studies of Violence and Sociopolitical Conflict (Berkeley, I995).

20 'Programa de desarrollo agropecuario en Río San Juan, Nicaragua,' unpubl. docum., Servicio Holandés de Cooperación Técnica y Social (SNV), I992, pp. 78-9.

21 J. Dunkerley, Power in the Isthmus: A Political History of Modern Central America (London, 1988), pp. 267-333, M. Dodson and L. N. O'Shaughnessy, Nicaragua's Other Revolution: Religious Faith and Political Struggle (Chapel Hill, 1990), pp. I45-75.

22 Marvin Ortega and Pedro Acevedo, 'Nicaraguan Repatriation from Honduras and Costa Rica,' in Mary A. Larkin et al. (eds.), Repatriation under Conflict in Central America (Dallas, I991), pp. I9-20.

${ }^{23}$ Jon Jonakin, 'Agrarian Policy,' in Walker, Nicaragua without Illusions, pp. 97-I I 3. 
percentage share of land occupied by peasant producers and co-operatives in Río San Juan increased from I 3 per cent to 44 per cent between 1978 and 1989. State farms, which were non-existent before the revolution, made up 50 per cent of the total farm area while the area occupied by large private landowners declined from 88 per cent to six per cent. ${ }^{24}$ The government also put great effort into improving education and health care in Río San Juan. Farmers benefited from easy credit terms, while popular organisations played a crucial role in incorporating local inhabitants into the political life of the country. ${ }^{25}$

Despite these improvements, the I 980 s was also a decade of tremendous conflicts for the people of Río San Juan. The war deeply divided the population: many male members of local households were recruited into the Sandinista army, while others were sent into the Contra camps. Both armies treated campesinos with excessive violence. Underage boys were inducted into the military and those who resisted taking up arms were coerced. In the public 'fervour' of the war, the battlefield was presented as a mythic birthplace of valorous combatants who were determined to fight to the end. ${ }^{26}$ For many soldiers, however, the reality was very different. Aurelio, who never spoke much of his experiences in the jungle, recalled his sufferings just briefly:

It was awful to be wandering around in the jungle, slogging through the mud. We went on sleeping where night overtook us, in a dark jungle. It rained and rained. Son of bitch! It was terrible to live in this fear and danger, having the enemy always on your heels. Be ready to kill or be killed. ${ }^{27}$

When leaving for the jungle, the soldiers talked about going adentro ('within') which meant disappearing into dangerous territories. Understanding the different sounds of the forest became a prerequisite for survival. The soldiers learned to distinguish the sound of a fruit falling or the sound of a tree crashing from whatever kind of noise that could mean that the enemy was near. Their eyesight sharpened from the strain of watching for the olive green enemy in the jungle, and many of them felt like Omar Cabezas that the dusk of the jungle almost suffocated them after months within it. ${ }^{28}$ Some

24 Utting, Trees, People and Power, p. I48.

${ }^{25}$ For Sandinistas' economic and social policies, see Gary Prevost, 'The Nicaraguan Revolution: Six Years after the Sandinista Electoral Defeat,' Third World Quarterly vol. 17, no. 2 (1996), pp. 307-27, Walker, Nicaragua without Illusions.

26 R. A. Montoya del Solar, 'Factured Solidarities: Utopian Projects and Local Hegemonies among a Sandinista Peasantry, Nicaragua, I979-1995,' unpubl. PhD diss., University of Michigan, 1996, pp. 195-6.

27 Author's interview, 7 Oct. 1996. The names of the interviewees have been changed.

28 O. Cabezas, Fire from the Mountain: The Making of a Sandinista. Transl. K. Weaver (New York, I985), p. 204. 
ex-soldiers still remembered their shock when for the first time they had to aim at the enemy and to see the suffering faces of the targeted. However, as committed guerrillas, they could not demonstrate the disgust and sorrow they felt.

Many civilians also found themselves trapped in the midst of the armed conflict and were obliged to leave. Thousands of people fled as refugees to Costa Rica, a great deal of them silently in order to make themselves less conspicuous. While the number of official refugees at Costa Rican refuge camps was calculated at 30,000 , the number of unofficial refugees and exiles was estimated at about 200,000. ${ }^{29}$ A great deal of these people left their land quickly, leaving behind their houses, crops, animals, and some of them even their family members. Many of them found the search for shelter in a foreign country humiliating; deprived of their resource and social bases, they suffered from all types of material and emotional loss.

At the same time, thousands of people were internally displaced by the war. Some of them were coerced into moving, but otherwise the Sandinista government was willing to assist internally displaced people. Despite this aid, many resettled people felt themselves to be alienated in their new surroundings, while those in the areas to which the displaced were moved found their lives disturbed by new population inflows. Resettlement evoked radical changes in production systems, as most of the settlements were organised as co-operatives. At the same time, the war altered household structure and gender roles. When young, productive men departed for combat, the elderly and very young were left to carry out the agricultural tasks. The number of female-headed households also increased significantly.

The fighting militarised both the agricultural production area and the wilderness. Every settlement maintained a vigilancia and farmers worked armed in the fields, keeping one eye on the horizon and the other on their immediate surroundings. The forest became a fearsome site of social terror, which the enemy used for refuge, supply routes, and ambushes. When people had to go to the forest, they marched quickly along the trails, listening for any change in the rhythm of birdcalls that might signal an ambush. ${ }^{30}$ Hunting was minimal because wandering in the forest constituted a risk. As a result, people's feelings toward the forest, which was traditionally seen as a source of danger from natural forces, became expanded into a view of the forest as a terrain of human-penetrated violence. Don Jesús remembered living under constant strain:

We didn't have much trouble with Contras, although we knew that they were in the jungle nearby. We had a permanent vigilancia. We worked by turns; when some of us

29 Ortega and Acevedo, 'Nicaraguan Repatriation,' p. 20.

${ }^{30}$ Cf. O. Cabezas, Fire from the Mountain, p. 204. 
were planting, others were watching the woods with weapons. Every one of us could handle a rifle. Preparing land for cultivation became very dangerous, because in a dense jungle you could never know in which brush they were lying in an ambush. ${ }^{31}$

Similar to other Central American civil conflicts in the I980s, attacks against civilians became a defining strategy of this 'dirty war'. Both armies were accused of gross human rights abuses, including tortures, rapes, disappearances, and murders of unarmed men, women and children. ${ }^{32}$ Public healthcare facilities, schools, and agricultural co-operatives became the prime targets of the Contras, who considered all the public work projects as part of a Sandinista strategy to ensnare the populace into the Socialist programme. ${ }^{\mathbf{3 3}}$ Many co-operative leaders and community activists had family members murdered before their eyes. Assuming that anyone could be a political enemy, people distrusted those they did not know and stopped giving information about their actions even to their nearest neighbours. Both armies worked with peasant collaborators who reported enemy movements and neighbours' suspicious activities. Those families who were forced to give food to the combatants did so with the fear of being accused of helping the other side, a claim that could cost them their lives. Such were the memories of doña Socorro:

They were so cruel. They came along and broke everything. They ransacked the house and forced me to say where my sons were hiding. Two of my sons were taken to the war, one of them, just fifteen years old, was killed in battle. To comfort me, they said that if the mother gets one of her sons back, she's fortunate enough $!^{34}$

In one way or another, the war touched every family in Río San Juan. Society was highly polarised and there were few opportunities to remain neutral. Many families became bitterly divided, having a son in the Sandinista army and another in the Contra. The ideological controversies were further sharpened by religious schisms, as the opponents of the Sandinistas tended to support conventional Catholicism or Protestantism, while many Sandinistas embraced ideas of liberation theology. Violence was an inevitable fact of life and, in some senses, it became difficult to distinguish the perpetrators from the victims.

31 Author's interview, i4 April i997.

32 Compared with the human rights abuses by the militaries in El Salvador and Guatemala, the Sandinista army's human rights record was, however, fairly good: systematic abuse of human rights was never a feature of the Sandinista military. See James Dunkerley and Rachel Sieder, 'The Military: The Challenge of Transition,' in Rachel Sieder (ed.), Central America: Fragile Transition (London, 1996), p. 70.

${ }^{33}$ See D. Eich and C. Rincón, The Contras: Interviews with Anti-Sandinistas (San Francisco, 1984), J. Kruckewitt, The Death of Ben Linder: The Story of a North American in Sandinista Nicaragua (New York, 1999).

${ }^{34}$ Author's interview, I 2 Nov. 1996. 
Part of the problem for civilians was that the war was sensed rather than seen. Gunshots were often heard in the distance, and people whispered that the enemy passed by, but nobody knew from where the next shot would come. ${ }^{35}$ The everyday handling of threats made some people perceive death as an incomprehensible mythic agent, which violently stole the lives of their loved ones. While some people of Río San Juan talked freely about their past sufferings, others felt it difficult to express their sorrow and preferred silence. Most of the women did not share their distress with other women in the neighbourhood; instead, they disguised their sense of injury in everyday representations of normality. Equally, men preferred not to discuss their military experiences with each other, but hid their traumatic memories behind displays of macho posturing. This refusal to share a history signals people's need to forget traumas, but it also suggests that in the still-polarised postwar conditions, there were few possibilities for people to relieve their past horrors. ${ }^{36}$

Despite these verbal silences, the memories of war and violence were an inevitable part of people's life histories that could not be ignored if their contemporary struggles were to be understood. Doña Catalina told of her sufferings after a great loss. She described how the Contras assassinated her husband, her daughter and her son-in-law because they worked in a co-operative. 'They murdered my family to make us afraid. Two of my grandchildren were orphaned, poor kids witnessed the brutal murder of their parents. I never forget how my husband looked when they killed him. They shot him in the head and opened his belly,' she said in a tremulous voice. 'But Thanks to God some people came to ask me how I was, and then I just said to them that: here I am, struggling (Aqui estoy, luchando). ${ }^{37}$

By the mid-I 980 s, about 62 per cent of the Nicaraguan national budget went on defence, crippling the government's programmes for social and economic reconstruction. ${ }^{38}$ Most of the people in Río San Juan did not perceive any improvement in their lives, and anxious about increasing hardships, they began to dream about the end of the war. Although Río San Juan was a region of strong Sandinista support, the government's relations with a segment of Río San Juan's peasantry proved to be disappointing. Many smallholders did not share the Sandinista vision that the road to raising their standard of living lay in collectivising their production or in becoming wage labourers on state farms. Drastic changes in production systems, together with economic crisis, reduced their enthusiasm for the revolutionary regime.

35 Cf. Kruckewitt, The Death of Ben Linder, p. 2 1 0.

36 Cf. Meertens, 'Facing Destruction,' p. I4I.

37 Author's interview, 2 I Nov. 1996.

38 D. Faber, Environment under Fire: Imperialism and the Ecological Crisis in Central America (New York, 1993), p. i 8 I. 
The majority of people had sacrificed scores of years for the hope of a more just society without seeing their hopes fulfilled. For them, peace became the issue of vital importance, it meant the possibility of returning to live without the daily threat of becoming victims of the war. ${ }^{39}$

\section{Difficult process of demobilisation}

While the Sandinistas' electoral defeat in 1990 ended the military fighting in Nicaragua, the process of national reconciliation revealed serious disagreements inherited from the war. An estimated 31,000 Nicaraguans, most of them civilians, died during the Contra War, and the country emerged from the conflict very weak. ${ }^{40}$ The double transition from war to peace and from a state-centred, planned economy to a neoliberal market model was anything but easy. The demobilisation of two armies $-22,000$ ex-Contras and 72,000 discharged members of the Sandinista Popular Army - was a complicated task. The peace agreements promised to provide land to those fighters who laid down their weapons, giving priority to Contra combatants. This issue turned out to be a principal source of tension in postwar Nicaragua, especially in Río San Juan and in northern parts of the country. ${ }^{41}$

The new government of Violeta Chamorro (1990-96) also promised a series of welfare programmes to facilitate the reintegration of ex-Contras into civilian life, including the establishment of special 'development poles'. These would include housing, plots of land for farming, roads, schools, hospitals, potable water and electricity - conditions far superior to those experienced of much of the rural population. One of the main areas that Contra leaders requested to be designated as a development pole was a I 6,ooo square $\mathrm{km}$ area in Río San Juan. ${ }^{42}$ This proposal was opposed, however, by the people of Río San Juan, particularly those sympathetic to the Sandinistas. Furthermore, the requested area overlapped with the protected area of Indio-Maíz, established as a part of the 'peace through parks' programme known as Si-A-Paz ('Yes-to-Peace'). This programme joined various nature reserves and wildlife refuges between Nicaragua and Costa Rica to an

39

For a detailed analysis of decreasing support for the Sandinista regime in southern Nicaragua, see L. Enríquez, Agrarian Reform and Class Consciousness in Nicaragua (Gainesville, I 997).

40 Thomas W. Walker, 'Introduction,' in Thomas W. Walker (ed.), Revolution and CounterRevolution in Nicaragua (Boulder, I991), p. 8.

41 Deena I. Abu-Lughod, 'Failed Buyout: Land Rights for Contra Veterans in Postwar Nicaragua,' Latin American Perspectives, vol. 27, no. 3 (2000), p. 33.

42 This figure of 16,000 square $\mathrm{km}$ is presented in Ortega and Acevedo, 'Nicaraguan Repatriation,' p. I 2. However, it seems exacerbated because the territory of the department of Río San Juan is only i 2,200 square $\mathrm{km}$. 
integrated system of protected areas. The joint management of these areas was promoted as an act of reconciliation between the two governments. ${ }^{43}$

The main areas of resettlement finally designated for Contra and Sandinista ex-soldiers were located in Río San Juan's interior and in various parts of northern Nicaragua. Concerned about national sovereignty, the government transformed the development poles to agricultural zones and reduced their size. However, most of the lands allocated for ex-soldiers were not suitable for agriculture. Soil fertility was fragile and could not sustain prolonged agricultural use. The resettlement programmes also lacked technical assistance to retrain the former fighters in agricultural production. Most of the regular soldiers in both armies were poor peasants and wage workers from the country's interior. Since many of them had spent a great deal of their lives as soldiers, they had little or no farming experience. The movement of these uprooted ex-combatants to Río San Juan presented a grave danger to the region's fragile peace. ${ }^{44}$ State officials did not even investigate whether the lands designated to ex-soldiers were unoccupied. Many of the demobilised people were given ownership of land already possessed by smallholders, but who, lacking legal title to the land were unable to file legal claims to their possessions. These controversies promoted deep hostilities between the demobilised people and local smallholders.

The policies of resettlement generally ignored the needs of non-combatant peasants and the civilian population that had borne the sufferings caused by the war. When the major fighting ceased in Río San Juan, a considerable number of displaced people returned to their farms, the vast majority without any assistance. During their absence, the lands of many returnees had been occupied by others, which prompted many conflicts. Many civilians felt bitter toward the government's policy of privileging ex-combatants and some of them went so far as to adopt ex-soldier identities in the hope that this would facilitate their access to land. ${ }^{45}$

Those returnees who had not lost their lands needed credit in order to resume production. Farm facilities had been devastated, and fields and pastures had gone unattended, all of which created an atmosphere of desperation. Whereas foreign powers supported each side of the conflict generously during the war, expected funds for reconstruction were not forthcoming. Many people languished in temporary plastic huts waiting for any kind

${ }^{43}$ Faber, Environment under Fire, p. I 80.

44 A. C. Armony, 'The Former Contras,' in Walker, Nicaragua without Illusions, p. 207. Among the demoblised people receiving land in Río San Juan, there were also various persons who had occupied a high rank in the Sandinista or Resistance army. Many of these highly educated persons never settled permanently in Río San Juan.

45 Ortega and Acevedo, 'Nicaraguan Repatriation,' pp. 43-5. 
of assistance. ${ }^{46}$ Various relief programmes worked exclusively with those returnees who had legal status and international protection in exile, while the needs of unofficially displaced people were overlooked. ${ }^{47}$ Such policies generated much tension and thus impeded the initiation of a reconciliation process. Fuelled by rumours circulating about the poor treatment of 'traitors', some returnees also feared reprisal. For others, emotional impediments made the return to their homeplaces difficult. Such was the case of doña Clara:

After the war, I left Che Guevara. I just couldn't imagine living there because the person who killed my husband was one of our neighbours there. My daughter still lives in Che, and whenever I visit her, I feel extremely aflijida (afflicted). God alone knows why I have to suffer so much. ${ }^{48}$

Equally affected by insecurity were the beneficiaries of the Sandinista agrarian reform land. Thousands of peasants and workers who had received land in the I980s now faced aggressive claims from former landowners emboldened by a government strongly representative of their interests. In principle, the Chamorro administration was committed to respecting the land tenure transformations effected by the Sandinistas. In practice, however, a counter-reform began almost immediately. The chaos that followed opened a flourishing market for speculative land purchases. Uncertain about the status of their land rights, many peasant producers, agrarian reform beneficiaries, and ex-combatants sold their lands at inordinately low prices. The beneficiaries were usually the relatively wealthy landholders, who possessed capital, access to credits, and political and marketing connections. ${ }^{49}$

The entire postwar period in Nicaragua has been characterised by conflicts over resources. In 1992 bands of recontras (rearmed Contras) and recompas (rearmed Sandinistas) mobilised a tactical alliance of the so-called revueltos, taking up arms together to pressure the government to respond to their demands. The Chamorro government's repeated attempts to buy out these rearmed groups rewarded violent forms of struggle and undermined the credibility of democratic procedures. This phenomenon is part of a larger process of the reconstitution of property rights in postwar Nicaragua that is still unresolved. Years of fighting and easy access to weapons have made violence a common means to resolve any kind of conflicts. ${ }^{50}$

46 Abu-Lughod, 'Failed Buyout,' p. 42.

47 Barry N. Stein, 'Reintegrating Returning Refugees in Central America,' in Kumar, Rebuilding Societies, p. 174.

48 Author's interview, I 2 March I 997.

49 More in this respect, see Jonakin, 'Agrarian Policy,' pp. 97-I I 3, Prevost, 'The Nicaraguan Revolution,' pp. 307-27.

50 Abu-Lughod, 'Failed Buyout,' p. 50. 
In Río San Juan, this movement has led to an upsurge of various rearmed bands and small gangs of rustlers who have created an atmosphere of insecurity. These groups represent a complex phenomenon of postwar violence that includes criminal activities, personal and political feuds, and socio-economic claims. Many ex-combatants believe that their chances of obtaining state support depend upon their capacity to stage military actions. ${ }^{51}$ Violent land invasions characterise Río San Juan, and in recent years these invasions have expanded to the reserve of Indio-Maíz. In a survey completed by the Ministry of Natural Resources in 1998 , three hundred families were recorded as squatting inside the reserve. Most of them were classified as 'invaders' who had already benefited from land redistribution in another region but who had then sold their land and moved further into the reserve. ${ }^{52}$ These conflicts have weakened the fragile local political stability and hindered the development of a viable civil society in this former battle zone.

\section{Postwar destitution: everyday troubles to earn a living}

After the end of the Cold War, Nicaragua was no longer the site of international rivalries and this impoverished country slipped from the global headlines. The trials of the Nicaraguan people were, however, by no means over. The structural adjustment policies initiated by the Chamorro government, and made much more stringent by the subsequent administration Arnoldo Alemán (I996-200I), worsened the standard of living of the majority of rural poor. ${ }^{53}$ Under the recent governments, there has been a tendency toward land reconcentration in Río San Juan, while tougher credit policies have placed many small producers in a precarious situation. More than 76 per cent of the population in the municipality of El Castillo lived in poverty in 1998 , and $4 \mathrm{I}$ per cent of them lived in severe poverty. ${ }^{54}$ The same tendency holds true all over Río San Juan as elsewhere in the countryside.

Although the majority of households in Río San Juan attempt to support themselves through agriculture, few of them are able to survive without temporally seeking off-farm or non-farm employment. Many households engage in a complex array of income generating activities, including cultivation of basic crops, mixed gardening, cattle or poultry husbandry, forest extraction, wage working, and itinerant trading. People move between spheres where different economic opportunities become available, and the

51 Armony, 'The Former Contras,' p. 2 I 4.

52 Author's interview with Iván Ortega, Ministerio de Recursos Naturales (MARENA), Managua, i9 Feb. 1998.

${ }^{53}$ Jenny Pearce, 'From Civil War to Civil Society: Has the End of the Cold War Brought Peace to Central America?,' International Affairs, vol. 74, no. 3 (1998), p. 589. See also 'A Strengthened Growth,' pp. 5-1 2. 
informal sector plays a crucial role in this frontier economy. This panoply of livelihood strategies exemplifies the elasticity required of these marginal people eking out a living in a context of great insecurity.

There are also high rates of intra- and interregional migration in Río San Juan. Many male household members work as seasonal labourers in Costa Rica or in urban settings. The remittances derived from family members working elsewhere form an important source of income for many households. Yet, despite the material advantages it brings, labour migration is seen as a sacrifice. When men are away for months, women are obliged to take over the agricultural tasks. Migration often develops into permanent family breakdown as husbands choose to abandon their wives and children altogether.

Children's participation in the myriad of household and agricultural tasks begins early, and their labour is highly valued. Children below school age carry out tiresome domestic chores such as gathering fuel wood, hauling water, grinding maize, making tortillas and looking after little brothers and sisters. By the age of twelve, children are considered able to perform adult agricultural and domestic tasks. They may also migrate to seek wage work elsewhere. Such was the case of Rolando:

I left my family when I was twelve years old. I wandered around looking for any kinds of jobs. My father drank too much and then he behaved very aggressively. He blamed us for just eating but not producing. The poverty and violence were just too much to bear. So I thought that if I left then there would be one less mouth to feed for my mother. ${ }^{55}$

The more familiar I became with local inhabitants, the more aware I became of the vulnerability of their lives. People worried about how to get by and many of them felt that their life was tied to 'looking for money' (buscando plata). Doña Yolanda described how she regularly rationed the meals to feed her family. For breakfast they ate tortillas and coffee, with no sugar, and the rest of the day consisted of gallo pinto (rice and beans). The few chickens she raised were reserved for getting some extra cash in the case of emergency ${ }^{56}$ Like many other women, doña Yolanda kept a careful account of every expense and had a precise idea of how much each item cost. She had to manage with what little her husband gave her and juggling this budget gave her many headaches. As with so many others, the family of doña Yolanda had little margin of safety to withstand unexpected economic shortfalls.

56 Author's interview, 2 Feb. I998. For similar testimonies, see Quesada, 'Contested Lives,' pp. $227-8$. 
The high costs of getting the harvest to market lead many people to sell their products to whatever traders might come. Knowing that the farmers want to sell quickly, the middlemen often set ridiculously low prices. Most of the households survive through pooling various small and irregular incomes. Despite the children's loyalty to their parents, the inequalities in terms of how much labour and how much money each family member contributes to domestic economy sometimes causes serious conflicts. The desperate shortage of cash makes some people interested in any sources of earnings and the frantic search for income leads some of them to illegal activities.

In recent years, the flow of new colonists entering Río San Juan has dramatically increased. ${ }^{57}$ Usually these migrants had left their previous places of residence because they felt that their livelihood possibilities were constrained. Most of them had no idea what they were getting into. They had heard of the 'fertile lands of Río San Juan' through rumours and made their way to Río San Juan with a glimmer of hope to find land of their own. Bewildered, they set up rustic ranchos and started to hunt for any possibilities to improve their livelihoods. Many newcomers faced serious difficulties in adjusting to this periphery. There was no electricity, no running water, and the few dirt roads connecting the settlements to the nearest town turned into a quagmire after every rain. Many farmers had to walk an hour or two to get to their fields. The newcomers told of their encounters with venomous snakes and their fear of jaguars, of the hardships to clear the jungle with a machete, and of the terrible malaria and lepra de la montaña. Some of them left the region after a few months, lamenting that they did not like the isolation; others decided to stay, struggling hard to get ahead.

In recent years, livelihood opportunities for these settlers living on the fringes of a protected area have been further complicated by resource use restrictions imposed by conservation authorities. From the conservationists' point of view, the biological reserve of Indio-Maíz is an irreplaceable sanctuary of biodiversity that should be preserved. In their portrayals, the reserve's rainforests appear as a vast resource domain, a biome of incredible richness, and a source of intellectual insights awaiting wide-eyed scientists. The reserve is the earth's green belt, a global carbon sink and an invaluable reservoir of genetic traits.

According to the National Census of Nicaragua, the population of Río San Juan was 20,832 in $197 \mathrm{I}$ and 70,143 in I995; a population growth of 240 per cent in 24 years. The Regional Planning Officials could not, however, confirm with any certainty how many people had settled in Río San Juan's interior in recent years. According to their estimate, ten to twenty new families come to this frontier every week, and the intensity of migration usually increases during the dry season, when the land is prepared for planting. Author's interview with Thelma González, Instituto Nacional de Reforma Agrária (INRA), San Carlos, 24 Nov. 1996. 
This perception, which satisfies national and global environmental agendas, is criticised by local inhabitants, who believe that the protection of nature has no justification if it is separated from local access to productive resources. Local people oppose the conservationists' idea of preserving large habitats as areas of untouched wilderness by pointing out that 'the outsiders seem interested only in parrots, monkeys and medicinal plants'. The environmentalism of these resource-poor peasants focuses on the social asymmetries in the control of natural resources in a situation where people feel their livelihood opportunities are constrained. Central to the self-image of local inhabitants is their involvement in 'taming the jungle' through hard work. They accept the limitations of their lives on the frontier because in their dreams the jungle offers not only a future of much effort and struggle, but also a possibility for planting today and harvesting tomorrow. For these settlers, the restrictive conservation policies pose a serious hindrance, prohibiting them from practising slash-and-burn agriculture and forcing them to apply for permits to undertake any type of resource extraction.

The issue that many conservation authorities have been reluctant to face is that the choice among sustainable land use practices is not simply between pristine wilderness versus destructive human use but between different kinds of uses and different forms of control. Many conservationists perceive local inhabitants as reprehensible invaders penetrating the majestic wilderness, and argue that 'this forest demolition should be controlled by harsh sanctions'. Some conservationists eagerly support the government's plans of employing a 'green army', composed of Nicaraguan military forces, to patrol Indio-Maíz and to force out the 'invaders' squatting inside the reserve. Government attempts to expel these squatters by military repression have proved unsuccessful, however, and instead have merely provoked a series of confrontations. It is very doubtful that such a hard-line approach to conservation ever achieves its objectives. Instead, coercive policies create a hostile attitude among local inhabitants towards nature protection, thus making conservation efforts untenable in the long-term. ${ }^{58}$

\section{Climate of fear and tension}

The lives of the people of Río San Juan also remain overshadowed by anguish and tension, in a situation where violent conflicts continue to plague

Of course, it would be unfair to suggest that the conservation authorities have a monolithic approach to protected area management or that all them have been insensitive to the needs of the local people. For more on these conflicts, see Anja Nygren, 'Environmental Narratives on Protection and Production: Nature-based Conflicts in Río San Juan, Nicaragua,' Development and Change, vol. 3 I, no. 4 (2000), pp. 807-30. 
the region. This atmosphere of hostility is closely interwoven with the government's insufficient efforts at postwar reconciliation, as well as with chaotic process of land speculation and a confused resource tenure system. However, when asked about the present situation, most people state 'Gracias a Dios, tranquila' ('Peaceful, thanks to God'), which suggests that despite the underlying pressure, life continues and effort is made to maintain a semblance of normality. In order to survive, people internalise a high rate of strain in their everyday lives. This tension often becomes manifested through somatic illnesses. Many people suffer from headaches, weakness, irritability and insomnia - disorders characteristic of dislocation and distress. The widespread nature of these complaints suggests that the somatisation of sufferings has become collective. ${ }^{59}$

The underlying tension also provokes feelings of resentment that create distrust within families and between neighbours. Separations and realigned family constellations test the limits of personal coping strategies, while political polarisation easily paralyses any effort for collective action. A crucial issue to consider in interaction with local residents is that the meanings invoked by many everyday words, such as 'colonist', 'settlement', or 'nongovernmental organisation', depend on the person's political affiliation. Many people do not like to speak of co-operation because it resembles the 'Sandinista vocabulary'. In an attempt to remove all vestiges of Sandinismo from the public discourse, the word co-operativa has been substituted by a euphemistic term asociación and the word campesino by pequeño productor. The same kinds of tensions and fractions emerge between men and women, Catholics and Protestants, long-term inhabitants and newcomers, and poor and more well-to-do people.

The aftermath of war also includes frustration, born of the thwarting of unrealised visions. Many people feel that the hope engendered by their commitment to the revolution has been dashed. 'We staked our lives for years. And we have come out worse than ever. I don't understand politics, that stuff, it doesn't interest me', said don Manuel who was once an eager supporter of the Sandinistas but who now denies any political affiliation. ${ }^{60}$ At one time, the Sandinista party represented a challenge to the political elites that had ruled Nicaragua for decades, while today many people see it as yet another authoritarian form of political control. Simultaneously, the Alemán government's widespread corruption, increasing obstacles to civil society activities, and lack of solutions to long-standing agrarian conflicts have

59 See Green, 'Fear as a Way of Life,' p. 239, Quesada, 'Contested Lives,' pp. 29-30.

60 Author's interview, 5 Oct. 1996. 
caused people to raise critical questions about the current rhetoric of 'democratisation'.

Similar unrest characterises 'private' life at home. Domestic violence has been recognised as a serious and pervasive problem in Nicaragua. The Demographic and Health Survey conducted in I 998 reports that 29 per cent of women stated they had been physically or sexually abused by their partners, and 60 per cent of them reported having been victims of violence when their children were present. ${ }^{61}$ In Río San Juan, most of these occurrences remain unreported. Women may stay in violent relationships for years for fear of reprisal, economic dependence on the abuser, and concern for their children. The vast majority of abused women in Río San Juan do not seek help through formal channels. In addition to their limited access to official assistance, many women distrust police and public institutions, which they consider to be corrupt and non-responsive. Domestic violence also creates shame and thus is concealed by its victims. I heard many second hand stories of physical violence and sexual abuse in Río San Juan, but these were always 'other people's problems'. Little by little, I became sensitive to these rumours, which proved to reveal valuable information also about the narrator's own life-situation. ${ }^{62}$

Simultaneously, structural adjustment policies have particularly marginalised women. Although the Sandinista policies in the I980s often subordinated women's interests to revolutionary goals, spaces were nonetheless opened for women to participate in various social, economic, and political arenas. This rhetoric of women's equal rights has changed in recent years to a patriarchal discourse emphasising women's restricted role in society. In I 997 the government replaced the Nicaraguan Women's Institute with the Ministry of the Family. The main duty of this new ministry is to foster traditional values about the family, defined as a married man and woman with the intention to procreate. Such a definition, celebrating the nuclear family, ignores Nicaraguan social reality, where common-law marriages have long been the main form of marriage for the poor, and a large number of households are headed by single mothers. Consequently, services offered for 'non-traditional' families have decreased. Many centres set up in the late I 980 s and early i 990s to provide psychological and legal services for battered women and single mothers have been closed, and educating schoolchildren about domestic violence has become more difficult because the Ministry of

${ }^{61}$ See 'A Strengthened Growth,' pp. I I-2, and M. C. Ellsberg et al., 'Women's Strategic Responses to Violence in Nicaragua,' Journal of Epidemology \& Community Health vol. 55 , no. 8 (200I), pp. 547-5. Estimates about whether domestic violence has increased in recent years are difficult to make because of the lack of systematic information about domestic violence in earlier decades.

62 See J. G. Townsend, Women's Voices from the Rainforest (London, I 995), p. 48. 
Education has prohibited women's movements from entering schools for this purpose. ${ }^{63}$

In the absence of institutional support, Río San Juan's women attempt to manage their marital problems by turning to informal institutions. When abuse is less severe, women defend themselves verbally or physically; when abuse becomes severe, they take their children and go to live with their mothers. Many women in Río San Juan are determined and outspoken. In the villages, where the houses afford little privacy, one could often hear an angry woman scolding her machista partner in a strong tone of voice. In recent years, women's movements have also made significant headway in moving the issue of domestic violence from homes to the political arena of public attention. At the same time, it is unlikely that these movements will transform long-term structures of domination in the near future. ${ }^{64}$

Another issue affecting psychosocial instability in Río San Juan is the question of providing justice for the victims of war. In a country which underwent no official attempts to uncover crimes that occurred during the war, many wounds remain. People were quickly pushed to 'reconcile', without a chance to air their grievances, clarify abuses, and call for restitution for human rights violations. ${ }^{65}$ Although most of the tragedies are now more than fifteen years in the past, many people still have difficulties in forgetting because 'there has been no justice'. Doña Amparo still has nightmares about the killing of her daughter who worked as a brigadista. 'She was so pretty and so conscientious', she says sadly while touching her daughter's photo decorating the family shrine. For doña Amparo, this yellowed photo serves in a situation as a strong reminder against forgetting within a context of official oblivion.

The experience of many war-torn societies has demonstrated that there are no easy answers for dealing with the legacies of past human rights abuses. ${ }^{\mathbf{6}}$ In Nicaragua, a broad political amnesty was granted for past human rights violators, while in El Salvador and Guatemala truth commissions were empowered to shed some light on past crimes. ${ }^{67}$ The main argument against prosecutions in Nicaragua was that politically charged trials would pose a risk of destabilisation during the fragile transition. However, public acknowledgement of, and accountability for, human rights violations is a crucial step to inhibiting the cyclical repetition of violence and to enable the conflictaffected population to recuperate. Some Latin American psychologists

${ }^{63}$ C. Chavez Metoyer, Women and State in Post-Sandinista Nicaragua (Boulder, 2000), pp. 97-I I 2.

${ }^{64}$ Ibid., pp. гог-1о.

${ }^{65}$ Spalding, 'From Low-Intensity War,' p. 56.

${ }^{66}$ For more on this, see Neryl Lewis, 'The Tasks of Political Recovery,' in Harris, Recovery from Armed Conflict, pp. 65-94.

67 Dunkerley and Sieder, 'The Military,' p. 66, Jonas, 'Can Peace Bring Democracy,' pp. 40-75. 
have noted a correlation between the sanctioned impunity of known perpetrators of human rights violations and a high level of latent fear and mistrust among citizens. ${ }^{68}$ In Río San Juan, most of the victimised are clear about what abuses took place and who carried them out. According to them, the official silence over the tragedies denies the validity of their sufferings. Many of them have little confidence in the country's judicial system as a means for resolving past injustices.

In such a climate of distrust it is difficult to achieve psychosocial reconciliation. The villages are tensely divided, and socio-economic instability has provoked an increase in common crimes. ${ }^{69}$ The general weakness of law enforcement agencies and the court system makes the rate of arrests and convictions low. This was clearly revealed to me in March 1988, when I visited the village of Kilómetro Veinte and heard that one of the local shopkeepers and his ten-year-old son had recently been assassinated. 'With the greatest cowardice they killed him, a man who worked for the congregation and never quarrelled with anybody. They came at night when he had just returned from the chapel and shot him in the back,' the widow of don Alejandro told me. Doña Sara looked exhausted and distressed. Her two children were playing in the dust while the eldest one was helping her at the store. 'If I had just been at home', she said bursting into tears, 'but I was visiting my parents in Nueva Guinea ... They are just waiting for me to leave and then they'll seize our farm. But no matter who dies, I'm not leaving,' she said firmly. ${ }^{70}$

Alejandro's murder paralysed the settlement with fear and there were many rumours of 'who and why'. The only persons who tried to investigate this violent assassination were two voluntary human rights activists, who worked at the risk of their own lives. Roger, one of the activists, explained to me how difficult the task was because 'anything smacking of human rights had to be done quietly. People first co-operate well, but when they should give an official testimony, they panic and prefer to keep their mouths shut. ${ }^{, 71}$ The existence of two rival human rights organisations - one pro, and one anti-Sandinista - testifies to the difficult polarisation existing in the region. Not surprisingly, the desire for tranquillity among local inhabitants is almost palpable. Many of them find it curious to learn that they are living in a post-conflict situation.

${ }^{68}$ Lewis, 'The Tasks of Political Recovery,' pp. 79-80.

69 The number of crimes reported to the police in the whole territory of Nicaragua was 8,056 in 1990 , this soared to I 8,037 for 1995, an increase of I I 2 per cent. Spalding, 'From LowIntensity War,' p. 5 I.

71 Author's interview, 28 Feb. 1998. 


\section{Struggles for reconstruction and resistance}

Despite all the pain and suffering, the stories of the people of Río San Juan were not merely litanies of worry and prejudice. They were also accounts of struggle and resistance, which included claims of worthiness and profound demands for life with dignity. Many people incorporated their own life-stories into wider discourses of human rights and struggles for social justice.

Of course, the possibilities of people reconstructing their lives varied considerably. Some felt that there was little hope, and that they had little control over the larger forces affecting their lives. There were also those who always blamed others for their plights. Sandinista-bashing was typical, especially of many middle-class producers. According to them, the country was bankrupted by an unnecessary war, and upright citizens' lands were confiscated to form unproductive co-operatives. Some people exaggerated the drudgery of their lives, expecting that outside supporters should resolve every problem.

At the same time, there were many people who showed an innate ability to face life challenges. Many of them had good organisational skills which helped them to overcome tragedies and undertake reconstruction. First of all, they had astonishing abilities to improvise when confronted with difficult situations. Natalia was one person who showed great resilience in a situation of chronic poverty. She had learnt to sew by herself and somehow had bought a second-hand, foot-powered sewing machine to work as a seamstress. Natalia's clientele was not very large, and she did not earn a lot, but what little she gained allowed the family to have some extra money. She also raised chickens, treated people with minor illnesses, and, despite her husband's opposition, participated in various community-based activities. Natalia always had a dozen plans to overcome hardship, as she herself put it: 'If my husband wants me to help him, he has to accept that I try to get money wherever I can. ${ }^{, 72}$

Many local inhabitants spoke of the need to share risks with each other in the community, at the same time emphasising that one should not confide even in one's nearest neighbour. 'I don't know people here, as I never leave. I leave the house only to do the laundry or to go to the church', many women claimed, while in the same breath stressing the significance of the community as one big family. Such strategies of negotiation, bargaining and reinterpretation were an important part of the processes through which local people re-established their identities. 
Local residents also astutely used the current language of sustainability, local participation, and sound resource utilisation. They often refused to do things they assumed I would disagree with, while selectively presenting images to please a foreign anthropologist. Some of them were involved in questionable commercial ventures while projecting themselves as humble campesinos. 'It's very bad to burn the land, I never burn my land, but my neighbours, you can never imagine what barbarous destruction they are wreaking' was a typical comment to explain the environmental degradation in the region. Many of them assured me that their whole farm was 'still covered by a dense forest, just a little piece of it is cleared', even if appearances belied such assurances.

Essentialist clichés of Nicaraguan peasants as an undifferentiated mass of rural poor, unable to contest power, are inappropriate in this situation. The complex interplay between local social processes and international development agendas during the last two decades has encouraged many people to reflect on their role in broader society and to seek alternative solutions to everyday problems. Although authoritarian political structures have not been removed, many previously invisible sectors of the population have found a political space, although fragile, to struggle, organise, and be politically represented. Different kinds of social movements have emerged throughout the country in recent years, including women's associations, peasant movements, indigenous organisations, religious movements and squatter organisations. ${ }^{73}$ These informal spheres of influence are vital conduits for achievement of basic needs by people neglected by governmental programmes. In Río San Juan these movements are not as yet very strong, but they are beginning to gain more influence, as Ricardo, one of the localgrassroots activists put it: 'Until the state ultimately reacts, we have already developed a dozen of our own strategies to overcome the problems. ${ }^{.74}$

Despite the stories of confrontation and conflict, anybody who spends time in Río San Juan also witnesses many examples of generosity and cooperation. There is much lending back and forth between neighbours and relatives are involved in myriad networks of mutual aid. According to local norms, food must be shared between relatives even when it is in short supply, and drinking water and lodging (posada) should not be denied to anybody. No one should be pinche (stingy) and one should never take advantage of someone else's generosity. I myself witnessed cases where a group of men carried a woman with complications in pregnancy or an injured neighbour in

${ }^{73}$ For Nicaraguan social movements, see Erica Polakoff and Pierre La Ramée, 'Grass-Roots Organizations,' in Walker, Nicaragua without Illusions, pp. I $85-20$ I.

74 Author's interview, 27 Feb. 1998. 
a blanket strung between two poles to the nearest health centre situated five hours' walking distance away. These informal networks of support are crucial to consider if we want to understand how people survive in situations of privation.

It is not my intent to sentimentalise the 'culture of poverty'. It is clear that the living conditions of local inhabitants are intolerable and that obligations to share meagre resources with all other members of the household cause many kinds of interpersonal tensions. Generosity does not mean an absence of self-interest. An implicit norm in the local lending networks is that the receiver should somehow compensate the favour. Doña Rosa worked as a voluntary midwife in the region. She often emphasised that she does not charge anything for her work. However, everybody seemed to know that the expected compensation for help in childbirth was one hundred córdobas if the baby was a male, fifty córdobas if it was a female. A person who neglects the norms of reciprocity develops a reputation as somebody who is not trustworthy, and if such behaviour persists they will be frozen out of all lending networks. ${ }^{75}$

The possibilities of local people contesting the wider structures of power should also not be exaggerated. In much of the contemporary literature, marginality is constructed as a progressive position of subaltern resistance while the informal sector is viewed somehow as an exotic network of coping strategies. Simultaneously, little attention is paid to the wider social, political and economic conditions in which these coping mechanisms and reconstruction struggles unfold. The virtual celebration of marginality and the argument that subaltern people define themselves in contrast to a hegemonic culture obscure the fact that structural exclusion is a central feature of uneven development and that the experiences of living in destitution are a reality for millions of people. ${ }^{76}$ This pattern does not support fatalistic thinking either, which suggests that poor people are passive and lack the will to overcome life challenges. Many people in Río San Juan, as elsewhere in Nicaragua, have repeatedly attempted to seize control of their lives and have purposely engaged in activities to overcome the limited situations imposed upon them. They have also shown incredible abilities to confront the tragedies and incorporate their personal hardships into larger sociopolitical processes and human rights struggles.

${ }^{75}$ For corresponding principles of reciprocity, see D. Cleary, Anatomy of the Amazon Gold Rush (London, I990), Pp. I $38-5$ I.

76 See Stephen Nugent, 'Verging on the Marginal: Modern Amazonian Peasantries,' in Sophie Day et al. (eds), Lilies of the Field: Marginal People who Live for the Moment (Boulder, 1999), pp. 179-95. 


\section{Conclusions}

This article has drawn on an ethnographic case study from Nicaragua to analyse people's everyday experiences of wartime violence and postwar distress. The main focus has been on the human dimensions of political conflicts and on people's lived experiences of dislocation and destitution. As such, this study has dealt with many broader issues, such as the traumatic processes of displacement and loss in prolonged civil conflicts, the delicacy of resource conflicts and human rights issues in postwar situations, and the difficult struggles for social justice and environmental equity by people living on tropical forest frontiers, conceptualised as 'hotspots of global biodiversity' in current conservation discourses.

The case of Nicaragua demonstrates that the signing of peace accords does not necessarily mean that political cleavages between former adversaries have been bridged. The population remains sharply divided and uprooted ex-combatants pose a continual threat to a fragile democracy. Traumatic memories of war and dislocation do not disappear overnight. This is especially evident in a situation where little attention was paid to psychosocial reconciliation and where many rehabilitation programmes worked only with officially recognised returnees. In recent years, a growing number of humanitarian organisations have realised that distinctions between the different categories of dislocated people tend to be artificial, and thus postwar assistance should target all the people uprooted by the war. ${ }^{77}$

In order to move from 'low-intensity peace' to a 'well-consolidated peace' great efforts are needed to encourage people to channel their demands through democratic processes instead of violence. Any attempts at postwar reconstruction should include efficient strategies for creating democratic institutions, strengthening civil society activities, and protecting human rights. Long-term possibilities for conflict resolution and negotiation between different actors are essential to promoting an atmosphere of co-operation and coalition-building, instead of resentment and revenge. ${ }^{78}$

Post-conflict reconstruction should also be sensitive to neither strengthening the economic power of the already powerful nor exacerbating competition between different stakeholders. Vast disparities in wealth, income and land ownership were at the root of the prolonged civil conflict in Nicaragua in the 1980 , and these inequalities continue to be the main source of political unrest and social tension in the country. There has been little amelioration of the structural sources of poverty and the state's efforts to respond to people's basic needs remain insufficient. Strict policies of structural

77 Kumar, 'The Nature and Focus of International Assistance,' pp. I 8-19, Stein, 'Reintegrating Returning Refugees,' p. I62.

78 Spalding, 'From Low-Intensity War,' pp. 49-5 I. 
adjustment and a government without ample representation may easily undermine the efforts for postwar reconstruction. ${ }^{79}$

Despite all the hardships and conflicts, many people in Nicaragua have demonstrated a remarkable ability to devise strategies to confront pervasive poverty and socio-political insecurity. They have also demonstrated the skills to negotiate, mobilise and build coalitions. This is not to idealise their struggles. Only if we connect local concepts of resilience and acts of resistance to larger processes of history and political economy can we fully understand subaltern people's struggles for survival and justice in devastating circumstances.

79 Pearce 'From Civil War,' p. 607. 